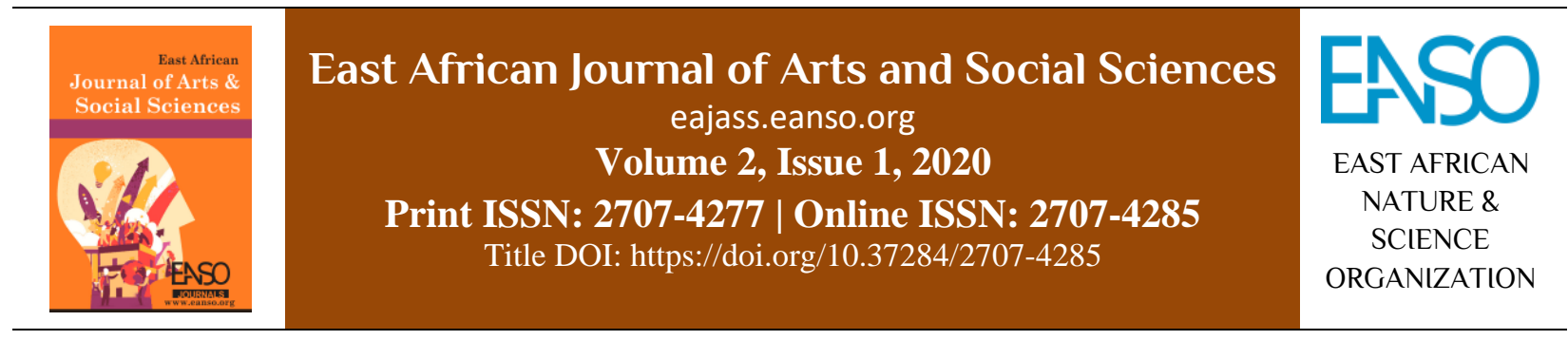

Original Article

\title{
Language, History, Ideology and Power Relations Used in Bullfighting Praise Poetry: A Case Study of Kakamega County, Kenya.
}

\author{
Mary Lukamika Kibigo ${ }^{1 *}$ \\ ${ }^{1}$ Masinde Muliro University of Science \& Technology, P. O. Box 190 - 50100, Kakamega, Kenya. \\ ${ }^{*}$ Correspondence email: kibigomary@gmail.com.
}

Article DOI: https://doi.org/10.37284/eajass.2.1.234

\section{Date Published: ABSTRACT}

31 December 2020 Language is a people's culture and it cannot be discussed singly without associating it to a certain community. The concept of bullfighting in the Isukha

Keywords: Community, Shinyalu Sub- County of Kakamega County in Kenya has a long

Language, History,

Ideology,

Power Relations,

Praise Poetry,

Shilembe,

Mayo,

Masculinity Theory,

Critical Discourse

Analysis Theory,

Bullfighting and

Masculinity. history as it involves chanting of words that portray masculinity in this community. The Isukha praise poetry that is chanted during the Shilembe ritual and the indigenous sport of Mayo is one of the ways in which masculinity is portrayed during bullfighting. In this praise poetry, language, history, ideology and power relations are portrayed by the artists. This article highlights the application of the Masculinity theory and Critical Discourse Analysis theory in the analysis of the language, history, ideology and power relations used in praise poetry during the ritual of Shilembe and the indigenous sport of Mayo to portray masculinity. Praise poetry was used because it is a genre that is commonly used during bullfighting; it is unique and peculiar in this context.

\section{APA CITATION}

Kibigo, M. L. (2020). Language, History, Ideology and Power Relations Used in Bullfighting Praise Poetry: A Case Study of Kakamega County, Kenya. East African Journal of Arts and Social Sciences, 2(1), 171-182. https://doi.org/10.37284/eajass.2.1.234

\section{CHICAGO CITATION}

Kibigo, Mary Lukamika. 2020. "Language, History, Ideology and Power Relations Used in Bullfighting Praise Poetry: A Case Study of Kakamega County, Kenya.”. East African Journal of Arts and Social Sciences 2 (1), 171-182. https://doi.org/10.37284/eajass.2.1.234.

\section{HARVARD CITATION}

Kibigo, M. L. (2020) "Language, History, Ideology and Power Relations Used in Bullfighting Praise Poetry: A Case Study of Kakamega County, Kenya.”, East African Journal of Arts and Social Sciences, 2(1), pp. 171-182. doi: 10.37284/eajass.2.1.130. 


\section{IEEE CITATION}

M. L. Kibigo, "Language, History, Ideology and Power Relations Used in Bullfighting Praise Poetry: A Case Study of Kakamega County, Kenya.”, EAJASS, vol. 2, no. 1, pp. 171-182, Dec. 2020.

\section{MLA CITATION}

Kibigo, Mary Lukamika. "Language, History, Ideology and Power Relations Used in Bullfighting Praise Poetry: A Case Study of Kakamega County, Kenya.". East African Journal of Arts and Social Sciences, Vol. 2, no. 1, Dec. 2020, pp. 171-182, doi:10.37284/eajass.2.1.234.

\section{INTRODUCTION}

The concepts of 'Shilembe' and 'Mayo' cannot be discussed singly without associating them with bullfighting. Bullfighting has a long history and it has been practised in various communities since time immemorial. This is a game that can be traced from Ancient communities like the Greek and the Romans. In Spain, 'Toreros' the bulls that are used during bullfighting are likened to the football players that are sponsored and shown in media. In this country, the bulls fight with people but there is normally a lot of caution such that no person is injured during the fight (Hemingway, 1932).

Kabaji (2008) explains that in France, during the $19^{\text {th }}$ century, the community members began bullfighting as a game of their own. The game continued and evolved up to the continents of Europe, Asia and Africa.

In East Africa especially in Tanzania, bullfighting was propounded by the Portuguese. The people of the Islands of Pemba and Unguja are believed to have initiated bullfighting with the Portuguese. During that time, the game was known as 'mchezo wa ng'ombe' that can be translated to 'the game of cows'.

In Western Kenya, this game involves a bull and another bullfighting using their sharp horns. In Mumias, for instance, the Wanga community call this game Eshiremba and it is done after burial where the bulls are brought on the grave and they fight and levelize the grave of a hero. The hero must be a man who has done a heroic deed like killing a wild animal, for instance, a lion, a cheetah or a python. The Maragoli refer to bullfighting as Ekeremba while the Banyore call it Shilemba (Alembi, 2002; Kabaji, 2005).
Matinde (2015) asserts that praise poetry has a vital role in portraying masculinity in various aspects of the community in question. Conversely, this paper focused on examining how language, history, ideology and power relations used in Isukha praise poetry during the ritual of Shilembe and the indigenous sport of Mayo portray masculinity.

\section{LITERATURE REVIEW}

Most scholars refer to the role of language in portraying culture in various communities. Previous researches indicate that people's language equals his or her identity. Moreover, a language is tied to people's culture hence an indicator of development in any community (Indede, 2012).

Nonetheless, many documents refer to the relationship between masculinity especially with ideology, history and the construction of masculinity in general with the issue of praise poetry, rituals and other disciplines. Previous literature on praise poetry portraying masculinity has shown that praise poetry plays a fundamental role in ensuring that masculinity is portrayed in various communities, however, some scholars emphasise on feminism (Obura, 1991).

\section{The concept of masculinity}

Various researchers define masculinity differently. This is due to the fact that different people have different perspectives and philosophical ideas that affect their views and ideologies (Hoffman, 1998).

Onyango (2011) explains that masculinity as a term began to be used during the pre-colonial period. It was used during storytelling sessions, in songs and in riddles. It was in such genres that characteristics of masculinity like patience, courage, humility, bravery and power were portrayed. 
Mdee (2015) identifies masculinity as the tricks that use power, strength and exploitation among others.

Masculinity is associated with the authority of men and their being able to succeed and take care of the family. He continues to say that a man is never born with masculinity as part of his reproductive organs but rather it is constructed and built in the tradition in which he grows (Walsh, 1997). On the same note, Wanjala $(2011,2015)$ explains that songs used by the initiates in the Bukusu community portray masculinity in a Bukusu man. He adds that this exalts him and gives him authority, power and characteristics of being heroic. According to Wanjala, circumcision is very vital because it is actually a symbol of authority and power to the male gender thus bringing about the concept of male chauvinism.

Choti (1998) describes masculinity as a way in which a man is depicted as having a power that is different from that of the female gender. He adds that men are normally seen from a positive perspective whereas women are viewed from a negative perspective. Choti's research focused on the female gender though it laid a good foundation for this research paper in terms of comparison.

\section{The meaning of praise poetry}

Praise poetry is a genre that is complex just like the concept of masculinity. It has compelled various scholars to come up with different definitions. According to Cope (1968), a praise poem offers admiration or worship of a person or god. Praise poetry continues to be a familiar literary form in various South African cultures. This scholar adds that the genre of praise poetry, called 'Isibongo' from the Zulu culture offers imagery and storytelling related to a person and the history that surrounds him or her. His research shows the praise poetry of the Zulu people, he explains that the person who chants the praise poetry in the Zulu community is known as 'Imbongi'. This refers to the narrator. These poems explain the general life of the Zulu people in terms of the traditions and ideologies of their community.

During the chanting of the Zulu praise poetry, cows are mentioned as very important in the life of the Zulu people. They were very important in laying a foundation for pointing out the praise poetry of the
Isukha community and their traditions and ideologies as a raw material to prove the relationship of power and authority in this community.

In Abatsotso praise poetry there is the role of praising the acts of heroism, confidence, trickster and bravery during wars. This arose from the dayto-day wars that took place in this community, journeys of hunting and always encountering with animals among other dangerous issues (Kunene, 1971).

Hodza (1979) on the Shona people points out that there are different types of praise poetry in this community, for instance, the clan praise poetry, personal praise poetry and praise poetry that involves being proud as a peacock. He analysed these praise poetries phonologically and morphologically. In his work, he has explained that these praise poetries are part of the traditions and ideologies of the Shona people. His work-related so well with this paper as it involved the aspects of linguistics like morphology, syntax and semantics. His research assisted our research in being able to analyse praise poetry basing on various clans of the Isukha community like the Vitsende, Vayokha, Vateheli, Vakhulunya, Vamilonje, Vimalia, Varimbuli, Varuli, Vatula, Vashilukha, Vasulwa, Vakhondi, Vatsunga, Vakusi, Vashilitsa, Vamakhaya, Vashimutu, Vaterema, Vateheli, Valila, Vasakala, Vakhaiwa, Vichina, Vimahalia, Vashitaho, Vasikhovu, Vakhombwa (Were, 1976).

Mulokozi (1996) explains that praise poetry is a chant of praising oneself, thus it is done by a character himself or herself. He further explains that praise poetry is constructed using imagery, metaphors, hyperboles and repetition among others. This work was vital to this research as it guided the researcher to analyse the language used in praise poetry to depict masculinity.

Praise poetry is where the art of speech that has performance enables one to put across his characteristics. This involves choosing specific words that affect the emotions of the audience. Praise poetry involves people, places, tribes, clans, races and ideologies to the community in question, basing on their history (Mwita, 1997). Therefore, it is necessary for any researcher to include the history of the community in question in order to 
discover the underlying features that are very important in oral literature research (Choti, 1998).

All the works of these scholars show that praise poetry as an art is grounded in the heroic acts of different communities.

\section{Research on language, history, ideology and power relations}

Massamba (2004) states that language is part of a people's culture and every community, therefore, has its own language that it uses to explain its 'own world'. A world that simply expresses their lifestyle. In this context, therefore, language is an important tool of communication that is used by the community not only to explain their world but also to create the overall view of the society about their life.

Literature is an art that expresses its themes through the language of words that is either spoken or written. The aspect of language is very important as it distinguishes literature from other forms of art (Senkoro, 1972). Therefore, in this context, language is a fundamental medium that gives an artist the authority to pass over to the audience intended themes, ideologies, perspectives, views and community values.

Mohamed (1995) says that language is the tool that carries ideas, $t$ is also an art that has its own value. Therefore, it calls for an artist to be very keen while selecting the following three things: the selection of words depending on the intended meaning to the audience, construction of the image and the results of the meaning built and the language that has the power to attract the audience.

Fiske (1994) says that words that are either spoken or written comprise of wider and varied ways in which a community is portrayed in terms of ideologies, history, economy and politics.

The various views of these scholars show how language is important as it is part of a people's culture. In the same way, in the Isukha community, the language used in praise poetry during the ritual of Shilembe and the indigenous sport of Mayo portray masculinity through the use of nouns like Spana, Master key, Mike Tyson, Eminyi, Tsinziga and $N A R C$ (Refer to praise poetry numbers: $1,5,6$, 7, 9, 11 and 15 in Kibigo, 2019 p: 146-153).

According to Webster Dictionary (2018), history is the study of or a record or story of past events considered together especially events or developments of a particular period, country or subject. History is like a bridge that enables one to cross over to the present then to the future. It enables one to realize the reality of life from its origin (Mwita 2005). He adds that people live depending on three tenses that are present, past and future.

This paper shows that masculinity does not evolve from a vacuum but rather it is constructed and portrayed from the expectations and ideologies that emerge historically from the culture of the community in question. It is from this context that some of the aspects are emphasized. This may include, for example, fierceness, patience, courage among other masculine characteristics regardless of whether they will bring disaster or violence to the community or not (Mwagike 2005). In the Isukha praise poetry, such characteristics are encompassed by an artist using selected specific aspects of language.

Choge (1997) suggests that it is important to consider culture in order to name a person. In the same way, the history of the Isukha community is important as the praise poems are chanted according to the ancestries, therefore naming comes in as it depicts masculinity through the names that are given to the bulls during bullfighting. Okal (2012) supports Choge's idea by saying that naming is very fundamental as it makes communication to be easier. In the same way, the naming of bulls during the ritual of Shilembe and the indigenous sport of Mayo is done basing on their culture and it eases communication as the audience is able to identify how masculinity is portrayed.

Masculinity in the community is built and constructed in different stages of history. Therefore, in order to understand masculinity in various communities, it is important to put into consideration the context of the history of that community. This paper shows that history is a vital aspect that contributes to creating and promoting philosophy and different perspectives of a certain 
community. Thus, this research involved finding out about the history of the Isukha people and their way of life in general so as to link it up with the praise poetry chanted during the ritual of Shilembe and the indigenous sport of Mayo. For instance, finding out about the clans of Isukha community and the origin of the ritual of Shilembe enabled this research paper to get the data to be analysed.

\section{THEORIES ADOPTED IN THIS RESEARCH}

Oral literature research can be guided by either one or more than one theory depending on the objectives of the research in question (Wanjala, 2011). Therefore, this paper adopted two theories in order to merge oral literature and linguistics hence bringing about a multidisciplinary approach in the research paper. These include:

Masculinity Theory (Izugbara, 2005) and the Critical Discourse Analysis Theory (Wodak, 1996).

\section{Masculinity Theory}

This theory was propounded by Robert Bly (Wells and Holland, 2001) and was continued by Izugbara in the year 2005. This theory shows how power and authority are possessed by the male gender especially due to the traditions of the community in question. The theory states that the term 'manhood' has its roots in biology whereas masculinity depends on the ideologies, perspectives and the expectations of tradition and depends on the particular community that is being referred to. Therefore, masculinity is born, raised and brought forth depending on the community.

The genesis of this theory is associated with the penis and those who possess it in the society as a powerful resource as far as the male gender is concerned. This makes the male gender to be considered as being powerful, respectful and of the high esteem in the society.

Walsh (1997) states that masculinity is shown or viewed in terms of the freedom of gender, competition, the authority to rule, control and also the power to order. While putting a lot of emphasis on the same point, Walsh (2001) adds that in the African community, masculinity is associated with the power to rule, order and control. This theory has four main tenets.
- Ideologies of the community that guide the mind and perspectives of the community members. This tenet assisted this research as it assisted in evaluating the way the Isukha community programmes the gender relationships in the performance of the ritual of Shilembe and the indigenous sport of Mayo and be able to portray masculinity through the praise poetry that is chanted by the artists.

- Secondly, the other tenet states that tradition life of the community and the relationships and the expectations of the community in question. The tradition of the community is portrayed through language, ideology and culture that show up in all the structure of the community as a whole.

- Thirdly, there's this tenet that explains how the responsibilities are divided depending on gender in the same way, responsibilities in the Isukha community are divided in a way that portrayed at how masculinity is portrayed at an early age. The praise poetry portrays this through the chants of the artists.

- Fourth, there's the tenet that states that there are specific characteristics that show that men or the male gender have specific characteristics that are peculiar and give them authority over the female gender. These are the characteristics that a man ought to possess in order to build, maintain and portray masculinity. These characteristics include patience, power, being courageous, promiscuous, firm and daring among other characteristics.

These tenets were very appropriate to this research as they guided it in the collection and analysis of data so as to achieve that objective of this paper. Even though, the research adopted the theory of critical discourse analysis in order to analyse the Isukha praise poetry in depth using the various aspects of language with a semantic view.

\section{Critical Discourse Analysis}

This is the second theory that was used in this paper commonly known as CDA, this theory was propounded by the following people; Teun Van Dijk, Fairclough and Wodak in 1990. It is grounded in different works of these proponents. It identifies the use of language in the society. Its main tenets 
are examining, power relations, history and ideology. Choge (2018) states that this theory needs assessing of discourse in a very keen manner, with an eagle's eye in order to experience the best results.

CDA is not a single theory but it is perceived as a way that has different perspectives of analysing the relationship between the use of language and the context of the community. The tenets that are commonly used are those of Van Dijk, Fairclough and Wodak (1997) Therefore, this theory focuses on the problems in the community. Thus, this theory does not just focus on the language but it also looks at its usage and also shades light of the linguistic characteristics of the community and traditions especially the concept of lack of gender equality and racial discrimination among other issues (Van Dijk, 1993). This theory assisted this work in analysing praise poetry discourse in-depth in order to portray masculinity in the Isukha community.

- The first tenet states that CDA focuses on the problems of the society. This was appropriate in this work as it helped the researcher to analyse the aspects of language in praise poetry in the Isukha community in order to identify how language aspects portray masculinity that brings about the problem of gender disparity.

- Power relations that come from speech. This tenet was important as it assisted in showing how relations in the society are portrayed in speech. This was useful as it showed clearly how the praise poetry that is chanted during the ritual of Shilembe and the indigenous sport of Mayo portrays masculinity. This theory clearly states that it is important to analyse any discourse in a deeper way in order to identify the assets of power that are within. This technique of deep analysis was borrowed from (Miruka, 2014) who used various citations in her work to come up with a lot of meanings and how forms of oral literature like songs and stories are found in Kiswahili literature hence bringing about intertextuality.

- The third tenet indicates that CDA relates the society with tradition. It aims at encouraging analysts to put in consideration tradition and the society in question in their analysis. A person's language is actually his /her identity. Therefore, this theory shows that the use of language contributes to changes in the society and the traditions of that society including power relations. This was vital in this paper as the praise poetry in the Isukha community were analysed on their clans - which includes their tradition and ideologies that were portrayed in the language used including nouns, phrases, verbs and also stylistic devices like metaphors, hyperboles and repetition.

- The fourth tenet states that discourse is history. Therefore, interpretation of discourse context. According to the CDA theory, it is clear that it cuts across all areas like linguistics tradition, society and ideology. This theory insists that it is important to focus on the history of the society in question in order to analyse any discourse in an easier and simpler way. In this paper, issues of history according to the Isukha community have been evident especially in the praise poetry during the ritual of Shilembe and the indigenous sport of Mayo. This has assisted the researcher to be able to identify and understand the Isukha man and the discourse that has a long history in this community. Fairclough (1995) explains that discourse is supposed to help an analyst to identify a certain action of the society depending on a particular perspective. Therefore, if the discourse is history, then it means that the praise poetry of the Isukha community is peculiar and different from that of any other community. This tenet was vital as it assisted the researcher to analyse masculinity in the Isukha praise poetry based on their clans.

One of the scholars who has used this theory is Matinde (2015), in his thesis "Masculinity in the Amabaiko of the Abakuria" $\mathrm{He}$ explains that masculinity is nurtured and constructed by the community in question, therefore, discourse is supposed to take caution in the choice of language, that is used in praise poetry so as to come up with the intended themes to the audience. In the same way, the CDA theory, helped this paper to identify the need of critically analysing the praise poetry in order to identify the language, history, ideologies and power relations that portray masculinity in the Isukha community. 


\section{THE RESEARCH AREA AND THE TARGET GROUP}

This research was done among the Isukha community who hail from Shinyalu Sub County in Kakamega County, Kenya. The target group were the Waisukha who are a subtribe of the Luhya tribe.

\section{SAMPLING PROCEDURE}

This research adopted the snowballing sampling technique. This helped the researcher to identify where the next performances of the ritual of Shilembe and the indigenous sport of Mayo were scheduled to take place. The research also used purposive sampling to sample seven clans that are famous in chanting praise poems, random sampling was also used to select nine praise poems in order to avoid biases. Therefore, the total number of praise poems that were used in this study were sixteen instead of twenty-seven that are equivalent to Isukha clans.

\section{LANGUAGE, HISTORY, IDEOLOGY AND POWER RELATIONS IN ISUKHA PRAISE POETRY THAT PORTRAY MASCULINITY}

Masculinity cannot be found in a vacuum. That is why the words of those with power are usually taken to be true and of great value than those who are seen as powerless in society (Van Dijk 2000). On this note, this paper found a basis of analysing how language, history ideology and power relations in Isukha praise poetry can create, portray and maintain masculinity.

Language is a very important aspect in the life of every human being. As language prospers, its literature also gets a gap of developing. In this regard, people's experiences are stored and developed. Therefore, praise poetry being a genre of poetry is very vital because it carries the traditions of a society.

King'ei \& Kemoli (2000) therefore assert that, basing on the chanting of Isukha praise poetry, it is clear that there are some special discourses that are used. These discourses are used by the artists who are also part of the society and have experienced a lot from the society in question. Therefore,
Masculinity in the ritual of Shilembe and the indigenous sport of Mayo was analysed basing on the following aspects:

\section{Language and Masculinity in Isukha Community}

As earlier noted, language is a medium of communication that is solely used by human beings. That is why in the Isukha praise poetry, it is the artist who chants and not the bulls. The bulls are only trained to fight and act according to the instructions given to them (Kabaji, 2008). The artist selects the language aspects to be used in the praise poems in a very creative and organized manner. This is not just done to make the praise poem to be appealing and gain aesthetic value but rather to bring about the views, perspectives, expectations and ideologies that construct and portray masculinity. By so doing, the artist carries the general views and expectations of the community that he hails from (Mohamed, 1995).

Critical Discourse Analysis identifies the use of language in the society. Its main tenets that really assisted this research include examining, power relations, history and ideology which are the main components of this research that cannot be realized without the medium of communication known as language.

One of the ways in which the artist uses language in the Isukha praise poetry is through naming the animals using the names that carry masculinity. Choge (1997) suggests that Onomastics is the discipline that is concerned with the giving of names to people or animals. Most specifically, Anthroponymy refers to naming human beings whereas animonymy refers to the naming of animals. She states that naming goes hand in hand with the traditions of the community in question. Okal (2012) notes that Onomastics is a discipline that is gaining popularity in the day-to-day life. He adds that naming eases communication. On the same note, naming of the bulls in the praise poetry during the Isukha bullfighting eases the understanding of how masculinity is portrayed. Table 1 therefore, shows how naming is used to portray masculinity in the Isukha praise poetry: 
Table 1 Language as it portrays Masculinity in Isukha praise poetry: Ref. in Kibigo 2019 p: 146-153.

\begin{tabular}{lll}
\hline Praise poem number & Names in Kiisukha/English & Masculinity \\
\hline 1 & Osama / Osama & Courageous/ fierce \\
5 & NARC / NARC & Political power \\
6 & Tsinziga / Horns & The act of erection \\
6 & Spana / Spanner & Prostitution \\
7 & Master key / Master key & Monopoly \\
9 & Eminyi / Name of a brave bird & Wisdom, courage \\
11 & Mike Tyson / Mike Tyson & Famous in Boxing \\
15 & Likhure / an owl & Dangerous ideologically/ bad omen/fierce \\
\hline
\end{tabular}

Source: Researcher's collection from the field

\section{History as it portrays Masculinity in Isukha} Praise Poetry

In oral literature, the culture of a community is transferred from one generation to another through the word of mouth. In the same way, the culture of the Isukha community that is found in praise poetry that is chanted during the ritual of Shilembe and the indigenous sport of Mayo is passed on to the next generation through oral transmission. That is why this research decided to tape-record the artists in order to preserve the culture of this community that portrays masculinity during bullfighting. The theory of Critical Discourse Analysis especially the works of Wodak $(1996,1999)$ show the importance of tracing back the history of a community in question in order to understand it better. This is simply because the past events form a good basis

\section{(Translator: The Researcher)}

for life today while on the other side the life today illuminates the future.

Connell (1995) notes that masculinity in the community is a reflection of different historical stages that make a basis on how power and authority are found and portrayed in the community. Similarly, in the Isukha praise poetry, history is an important aspect that forms a basis of analysing masculinity through for instance ancestral linkages. In this community, the artists are known to chant these poems based on their specific clans. The research discovered that there are some clans that are more superior than others. For example, the following praise poem depicts how one of the Isukha clans is praised for being able to produce very tall men that are nine feet long, this is a sign of power and physical strength. Refer to the following praise poem:

Table 2. Praise poetry No. 1: Refer to Praise poetry No. 11 in Kibigo 2019 p:150.

Isukha Dialect

Nuwisunda himbi handi
Kenyanga wekasie ubulahi
Habula olanyakhana
Rulanga mumuliango kwa Abisende
Mwene tsichirishi tsyobucheli
Vamanya khukhola avakhali vanyole tsinda
Avasiani varambi tsifuti tisa

Source: The Researcher, from the field

In this praise poetry, the artist uses language in the form of hyperbole and relates it to the history of the Isukha community where he tells us about the way the Abisende clan possess bulls that have wisdom and they know how to look for wealth in the society. It is the male gender that possesses the bulls in the

\section{Translation in English}

If you move closer to me

You need to prepare well

Otherwise, you will suffer

I hail from the Abisende clan

The owner of bright bulls

They know how to make women pregnant

Tall boys of nine feet

\section{(Translator: The Researcher)}

Isukha community. There, they are the only ones who are bright and have wisdom. They are seen as the ones who know how to 'sleep' with women and impregnate them. In other words, the artist finishes the chant by saying that the children that are born 
are tall boys with nine feet that can be broken into two to produce two men.

In this praise poetry, the artist is trying to use a form of stylistic device to show us that the idea of the boys possessing nine feet is associated with masculinity according to the culture of the Isukha community. The height of a man that is tall is a characteristic that is viewed in a positive way whereas one of shortness is seen as negative. In this part, the artist has used the idea of a tall man to portray masculinity. Even though a short man is compared to a hammer, there are some artists who argue that the shortness of a man doesn't matter what matters is his power, authority, strength, power, authority, strength, proves and his struggle to produce wealth. This is portrayed in the following praise poetry;

\section{Praise poetry No. 2: Refer to Praise poetry No. 16 in Kibigo 2019 p:153.}

\section{Isukha Dialect}

Khali nikaba ichilishi ni itsimbi, Shindu shikali ni khukhaba buhinda Munjila yukhumbakha litala lilie Khuvirila mukhwira mutsiku. Source: The Researcher in the field

When we look at this praise poetry and analyse it critically using the CDA theory, it is clear that even though a man may be short physically, what matters is his initiative and efforts in searching for wealth and being in a position to build his home. This also shows that the idea of searching for wealth is an appropriate pillar of masculinity as far as expectations of the Isukha community are concerned. In this community, therefore, it is evident that the female gender depends on the male gender to provide for them hence this makes them fully dependant on the male gender. This arises due to the fact that it is supported by the traditions and ideologies of the Isukha community that tend to value the male gender and diminish the female gender.

\section{Ideology and power relations in the Isukha praise poetry}

Each community has its own ideologies that guide it. Webster Dictionary (2019) defines ideology as a set of opinions or beliefs of a group or an individual. It further states that ideology refers to a set of political beliefs or a set of ideas that characterize a particular culture. In this context, the Isukha community possesses various ideologies that play a major role in constructing masculinity. These ideologies rotate around their culture and are evident or heard when the artists chant the praise poetry during the ritual of Shilembe and the indigenous sport of Mayo. For instance, when the

\section{Translation in English}

Even though a bull may be short, what matters is to search for wealth as he builds his own place in the process of killing his enemy. (Translator: The Researcher)

artist names a bull by the name Likhure in Isukha which refers to an "owl" in English, (refer to Table 1 , praise poetry no. 15). This means that masculinity is associated with bad omen with regard to the owls (Heimbuch, 2015). Therefore, it is clear that a real man should be fierce and ready to die because, in the Isukha community, an owl cries as a sign that someone is likely to die. This and other signs like a bull not being able to urinate on the grave during the ritual of Shilembe denotes infertility in the community among other ideologies (Kabaji, 2008). Therefore, these ideologies cannot be discussed singly as they depict power relations and hence masculinity in the Isukha community.

Therefore, the two theories, hegemonic masculinities and critical discourse analysis assisted this work to identify the masculinity characteristics in Isukha praise poetry and critically analyse them to come up with the language, history, ideology and power relations that are encompassed in them.

\section{CONCLUSION}

This research has proven that the ritual of Shilembe and the indigenous sport of Mayo is not just a celebration but rather it creates a platform where the Isukha community can use to portray masculinity through language, history, ideology and power relations. 


\section{RECOMMENDATIONS}

This paper recommends that more scholars need to do multidisciplinary research in-depth involving oral literature and linguistics.

The praise poetry that is chanted during the ritual of Shilembe and the indigenous sport of Mayo should be preserved technologically in order to benefit the future generation.

Research should also be done on other genres of oral literature that portray masculinity.

More research to be done on other language aspects that portray masculinity.

\section{REFERENCES}

Alembi, E. (2002). The Construction of Abanyore Perceptions on Death through Oral Funeral Poetry. Tasnifu ya Uzamifu. Helsinki: Ndaki ya Helsinki (Haijachapishwa).

Choge, S. C. (1997). Anthroponimu Asilia za Kinandi kwa Mtazamo wa Kisemantiki. Tasnifu ya Uzamili: Eldoret: Ndaki ya Moi.

Choge, S. C. (2018). Makala ya Mhadhara wa Kozi ya Uchanganuzi Makinifu wa Diskosi kwa Wanafunzi wa Kiswahili wa Uzamifu. Kakamega: Ndaki ya Masinde Muliro.

Choti, J. N. (1998). Language and Hierarchy: The linguistic Portrayal of Gusii Woman. M.A Thesis. Nairobi: Kenyatta University.

Connell, R. W. (1995). Masculinities. Berkey: University of California Press.

Cope, T. (1968). Izibongo: Zulu Praise-Poems. Oxford: Oxford University Press.

Fairclough, N. (1989). Language and Power. New York: Longman.

Fairclough, N. (1991). Language in the News: Discourse and Ideology in British Press. London: Routledge.

Fairclough, N. (1992). Discourse and Social Change. Cambridge: Polity Press.
Fairclough, N. (1995). Critical Discourse Analysis: The Critical Study of Language. London: Longman.

Fairlough, N. (2002). The dialectics of discourse.Textus, 14(2), 3 - 10. Retrieved from http://www.ling.lanes.ac.uk/staff/norman/2001 a.doc $7 / 8 / 2018$.

Fiske, S. T. (1990). Controlling other People: The Impact of Power on Stereotyping. American Psychologist, 48, pp 621-628

Heimbuch, J. (2015). 5 myths and superstitions about owls. https://www.com/earth matters/animals/blogs/

Hemingway, E. (1932). Death in the Afternoon: Treatise on Spanish Bullfighting. Retrieved on 1st September 2018.

Hemingway, E. (1932). The Sun Also Rises: A Novel that includes many accounts of Bullfighting. Retrieved on 2nd September 2018.

Hodza, A. C. (1979). Shona Praise Poetry. Oxford: Oxford University Press.

Indede, F. N. (2012). Makala ya Mhadhara kwa Wanafunzi wa Uzamifu katika Kiswahili: Ushairi wa Kiswahili. Maseno: Ndaki ya Maseno.

Izugbara, C. O. (2005). "Hypothesis on the Origin of Hegemonic Masculinity" In Sexuality in African Magazine. Lagos Africa Regional Sexuality Resource Centre 2 (1), pp 13-14

Kabaji, E. (2005). The Construction of Gender Through the Narrative Process of the African Folktale: A Case Study of the Maragoli Folktale. $\mathrm{PhD}$ Thesis. University of South Africa.

Kabaji, E. (2008). Masculinity and Ritual Violence: A study of Bullfighting among the Luhyia of Western Kenya. Pdf retrieved on 17/9/2018.

Kibigo, M. L. (2019). Ubabedume katika Majigambo ya Miviga ya Shilembe na mchezasili wa Mayo miongoni mwa Waisukha Nchini Kenya kwa Mtazamo wa Semantiki. Chuo Kikuu cha MMUST. Tasnifu ya Uzamifu 
iliyowasilishwa kwa Utahini. Kakamega: Ndaki ya Masinde Muliro.

King'ei, K. \& Kemoli, K. (2001). Taaluma ya Ushairi. Nairobi: Acacia Stantex Publishers.

Kunene, D. P. (1971). Heroic Poetry of the Basotso. Oxford: Oxford University Press.

Massamba, D. P. B. \& Wenzake (2004). Fonolojia ya Kiswahili Sanifu (FOKISA). Sekondari na Vyиo. Dar es Salaam.

Massamba, D. P. B. \& Wenzake (2004). Kamusi ya Isimu na Falsafa ya Lugha. Dar es Salaam: TUKI.

Matinde, R. (2015). Uchanganuzi wa Ubabedume katika Majigambo (Amabaiko) ya Abakuria. Tasnifu ya Uzamifu: Laikipia: Ndaki ya Laikipia.

Mdee,J. S. (2015). Kamusi ya Karne ya 21: Kamusi ya Kiswahili yenye Uketo Zaidi katika Karne Hii. Nairobi: Longhorn Publishers (K) Ltd.

Miruka, F. A. (2014). Maumbo ya Fasihi Simulizi katika Mashairi Andishi ya Kiswahili. Tasnifu ya Uzamili. Maseno: Ndaki ya Maseno.

Mohamed, S. A. (1995). Kunga za Nathari ya Kiswahili. Nairobi: East African Educational Publishers.

Mulokozi, M. M. (1996). Fasihi ya Kiswahili. Dar es Salaam. TUKI.

Mwagike, L. (2005). "An Assessment of the Factors that Hinder Women's Movement and Empowerment: The Crisis of Masculinity in Tanzania Perspectives" In Uchendu, E. (ed.) Masculinities in Contemporary Africa.CODESRIA Gender Institute, Session, June, 2005.

Mwita, B. M. (2005). Dhima ya Ichingero za Wakuria Kusawiri Taswira ya Mwanamke. Tasnifu ya Uzamifu. Eldoret: Ndaki ya Moi.

Obura, A. P. (1991). Changing Images: Portrayal of Girls and Women in KenyanTextbooks. Nairobi: ACTS Press.
Okal, B. O. (2017). Nafasi ya Tafsiri Katika Taaluma za Onomastiki: Uhakiki wa Mbinu Zake Katika Tafsiri ya Toponomastiki. Kiswahili, 75(1).

Onyango, J. O. (2011). Discursive Masculinities and the War Against AIDS: The Kenyan Experience. Division of Research and Extension, Egerton University- Kenya.

Senkoro, F. M. K. (1982). Fasihi na Jamii. Dar es Salaam: Press and Publishing Centre.

Senkoro, F. M. K. (2011). Fasihi. Dar es Salaam: Kauttu Limited.

Van Dijk, T. A. (1998). Ideology: A Multidisciplinary Approach. London: Sage.

Van Dijk, T. A. (2000). Critical Discourse Analysis. Discourses in Society website. http://www.discourses.org/OldArticles/Critical $\%$ 20discourse\%20analysis.pdf on 3/8/2019.

Van Dijk, T.A. (1993). Discourse and Society. London: Sage.

Walsh, C. (2001). Gender and Discourse; Language and Power in Politics, the Church and Organizations. London: Longman.

Walsh, M. R. (1997). Women, Men and Gender: Ongoing Debates. London: Yale University Press, New Haven.

Wanjala, S, F. (2011). Kitovu cha Fasihi Simulizi: Kwa Shule, Vyuo na Ndaki. Mwanza: Serengeti Educational Publishers (T) Ltd.

Wanjala, S. F. (2015). Mwingilianotanzu katika Fasihi Simulizi ya Kiafrika: Mfano wa Embalu na Mwaka Kogwa. Tasnifu ya Uzamifu. Nairobi: Ndaki ya Kenyatta.

Wells-Wilbon, R \& Holland, S. (2001. December). Social learning theory and the Influence of male role models on African American children in PROJECT 2000.

Were, G. S. (1976). A History of the Abaluhya of Western Kenya 1500 - 1930. Nairobi: E.A.P.H. 
Wodak, R, (1999). Introduction in R. Wodak (ed.), Language, Power and Ideology. Amsterdam: Benjamins.

Wodak, R. (1989). Language, Power and Ideology: Studies in Political Discourse. Amsterdam: Benjamins Publishing Company.

Wodak, R. (1996). Critical Linguistics and Critical Analysis: A Handbook of Pragmatics. Amsterdam: Benjamins.

Wodak, R. (2001). What CDA is about-a summary of its history, important concepts and its developments. Methods of critical discourse analysis, 1, 1-13. 